\author{
S. Sapanov' ${ }^{1}$ iD , B. Baytuganova ${ }^{2}$ \\ Atyrau State University named after H. Dosmukhamedova, Kazakhsnan, Atyrau city, \\ 1e-mail: zhangabay@gmail.com \\ 2e-mail: aynura_ktl_92@mail.ru
}

\title{
REFLECTION OF KAZAKHSTAN-BRITISH CULTURAL RELATIONS IN MEDIA
}

The purpose of the study is to give a general description of the problem of reflecting Kazakh-British cultural ties in the media. In the changing world of today, journalism also requires a new look, new concept, and new thinking. Over time, foreign policy has set new challenges for the media. An example is the cultural sphere in international relations. The article talks about the role of the media in ensuring unity and stability in covering international relations and about cultural ties in harmonizing international relations. Indeed, modern international relations cannot be imagined without culture, since culture is an integral part of country's strategic activities, being an effective tool in international relations. Media, as an effective tool for the harmonization of international relations and cultural relations, allow the state to seek openness and dialogue, to form a positive image of the country and to promote national interests. At the same time, according to the media, the cultural and historical ties between Kazakhstan and British, the key models of their foreign cultural policy, the importance of cultural policies in these countries and the important milestones in cultural cooperation are classified. They are marked by the gradual development of cultural ties and important events in the entire history of cooperation between the two countries. As a result, the initiatives of the heads of state in the cultural context were demonstrated in establishing and maintaining fair and mutually beneficial relations, and today the role of media in furthering and expanding the cultural ties between the two countries was emphasized. The importance of the work complements the existing understanding of the role of cultural factors in the foreign policy of states, as well as the current state of the media in both countries. Research materials can be used for further research in these areas.

Key words: media, cultural relations, manuscripts, foreign policy.

\section{С. Сапанов ${ }^{1}$, Б. Байтуғанова ${ }^{1}$}

${ }^{1}$ X. Аосмұхамедов атындағы Атырау мемлекеттік университеті, Қазақстан, Атырау қ., 'e-mail: zhangabay@gmail.com

2e-mail: aynura ktl 92@mail.ru

\section{Қазақстан мен Британия арасындағы мәдени} қарым-қатынастардың БАҚ-тағы көрінісі

Зерттеудің мақсаты - БАҚ-тағы Қазақстан мен Ұлыбританиялық мәдени қатынастарды бейнелеу мәселесіне жалпы сипаттама беру болып табылады. Бүгінгі өзгеріп жатқан әлемде журналистикала жаңа көзқарас, жаңа түсінік, жаңа ойлауды қажет етеді. Уақыт өте келе сыртқы саясат БАҚ үшін жаңа міндеттер қойды. Мысал ретінде халықаралық, қатынастардағы мәдени саланы айтуға болады. Мақалада бұқаралық ақпарат құралдарының халықаралық қатынастарды жариялаудағы бірлік пен тұрақтылықты қамтамасыз етудегі рөлі және халықаралық қатынастарды үйлестірудегі мәдени байланыстар туралы айтылады. Шынында да, қазіргі халықаралық қатынастарды мәдениетсіз елестету мүмкін емес, өйткені мәдениет - бұл халықаралық, қатынастардың тиімді құралы бола отырып, елдің стратегиялық қызметінің ажырамас бөлігі. Бұқаралық ақпарат құралдары халықаралық қатынастар мен мәдени қатынастарды үйлестірудің тиімді құралы ретіндемемлекетке ашықтық пен сұхбаттастыққа, елдің оң имиджін қалыптастыруға және ұлттық мүАделерді алға жылжытуға мүмкіндік береді. ӘАіснамалық негіздегі контентті та^дау қазіргі БАҚ-тағы екіжақты мәдени қатынастардың негізгі тақырыптарын ашты. Сонымен бірге, бұқаралық ақпарат құралдарының ағымымен, Қазақстан мен Ұлыбритания арасындағы 
мәдени және тарихи байланыстар, олардың сыртқы мәдени саясатының негізгі модельдері, осы елдердегі мәдени саясаттың маңыздылығы және мәдени ынтымақтастықтағы маңызды кезеңдері жіктелген. О^ сонымен бірге халықаралық мемлекетаралық қатынастарға айтарлықтай әсер ететін мәдени факторлардың деңгейлерін қарастырды және мемлекетаралық ынтымақтастықтың маңызды кезеңдеріне назар аудары^ды. Олар мәдени байланыстардың біртіндеп дамуымен және екі ел арасындағы ынтымақтастықтың бүкіл тарихындағы маңызды оқиғалармен ерекшеленеді. Нәтижесінде, мемлекет басшыларының мәдени контекстегі бастамалары әді^ және өзара тиімді қатынастарды орнатуда және сақтауда көрсетілді, ал бүгінде екі елдің мәдени байланыстарын одан әрі кеңейтудегі БАҚ рөлі атап өтілді. Жұмыстың маңыздылығы мемлекеттердің сыртқы саясатындағы мәдени факторлардың рөлі туралы қалыптасқан илеяны, сондай-ақ екі елдегі ақпарат құра^дарының қазіргі жағдайын толықтыратындығында. Зерттеу материалдарын аталмыш мәселелер бойынша ғылыми ізденістерді дамыту үшін пайдалануға болады.

Түйін сөздер: БАҚ, мәдени қатынас, қолжазбалар, сыртқы саясат.

\author{
С.Сапанов ${ }^{1}$, Б. Байтуганова ${ }^{2}$ \\ Атырауский государственный университет имени Х. АосмухамеАова, Казахстан, г. Атырау, \\ 'e-mail: zhangabay@gmail.com \\ ${ }^{2} \mathrm{e}-\mathrm{mail}$ : aynura_ktl_92@mail.ru \\ Отражение казахстанско-британских кумьтурных отношений в СМИ
}

\begin{abstract}
Цель исследования - дать общее описание проблемы отражения казахстанско-британских культурных связей в среАствах массовой информации. В быстроменяющемся, сегодняшнем мире такая важная сфера как журналистика, также требует свежего взгляАа, новой концепции и нового мышления. Современная внешняя политика ставит перед СМИ новые задачи: примером является культурная сфера в международных отношениях. В Аанной статье говорится о роли СМИ в обеспечении единства и стабильности при освещении межгосударственных дел и о культурных связях в гармонизации международных отношений. Аействительно, современные международные отношения невозможно представить без культуры, поскольку культура является неотъемлемой частью стратегической деятельности страны, эффективным инструментом в межАународных отношениях. СМИ, как эффективный инструмент гармонизации международных отношений и культурных связей, позволяют государству стремиться к открытости и Аиалогу, помогают сформировать позитивный имидж государства и продвигать национальные интересы. Контент-анализ в методологической основе показа^, в каком свете представлены двусторонние культурные связи в современных СМИ; позволил определить их основную тематику, гАе показаны классификация культурных и исторических связей между Казахстаном и Британией; отражены ключевые модели их внешней политики, важность культурной политики в этих странах, основные вехи в их культурном сотрудничестве. Рассмотрены уровни культурных факторов, которые оказывают значительное влияние на международные межгосударственные отношения, и сосредоточено внимание на ключевых этапах межгосударственного сотрудничества. Они отмечены постепенным развитием культурных связей и важных событий за всю историю сотрудничества двух стран. Наряду с этим рассматриваются основные инициативы глав государств по установлению и подАержанию добросовестных и взаимовыгодных отношений в культурном контексте, и подчеркнута роль СМИ в расширении культурных связей между Авумя странами. Значимость работы состоит в том, что она Аополняет существующее представление о роли культурных факторов во внешней политике государств, а также современном состоянии СМИ Авух стран. Материалы исследования могут быть использованы Аля дальнейшей научной разработки проблемы и в учебно-методической работе.
\end{abstract}

Ккючевые слова: СМИ, культурные отношения, рукописи, внешняя политика.

\section{Introduction}

Materials on the methods of building interstate relations in the domestic media regularly appeared both in specialized publications and history textbooks, and on the pages of newspapers and magazines. Currently, in the process of development of Kazakhstan, serious secular changes are taking place. Today is not like yesterday. According to researchers, Kazakhstan needs to embark on the path of sustainable development in order to join the world of highly developed, civilized countries. If we are not developing economically, environmentally friendly, and at least we need to hurry so as not to fall into the dust at the end of migration, and go forward and not return in difficult times. The problem is solved not only by complex 
economic conditions, but also by cultural relations, it is necessary to develop the moral motivation of the individual, motivate spiritual growth, and bring about the effects of literature, art (Akiner,1995). And many media materials say that modern international relations cannot be imagined without culture. Culture is an integral part of the strategic actions of a certain country in the international arena, since it occupies a decisive characteristic of foreign policy (Alaolmolki, 2001). That is, cultural diplomacy is recognized as one of the official spheres of foreign policy. In short, cultural diplomacy is an important area of diplomatic activity of many countries. That is why cultural ties can be an effective tool in international relations. Because cultural relations allow a certain state to seek openness and dialogue (Tishkov, 1995). This is worth mentioning. It is also known that today many of the leading countries of the world are actively using the methods of foreign cultural relations, that is, the use of cultural potential is of particular importance. The reason is that it is important to strengthen inter-civilization partnerships in the creation of new world order, to combat global conflicts on cultural and religious grounds. Of course, cultural interaction remains an important factor in relations between states, since cultural relations play an important role in uniting nations, including mutual understanding between peoples, maintaining peace, resolving conflicts and protecting human rights (Orazbekova, Zhanabaev, 2017). What Does the Bible Really Teach USA, Great Britain, France, Germany, etc? Cultural dimensions play a decisive role in the foreign policy of these leading countries. Therefore, today's world aspires to develop cultural relations as an effective tool for international co-ordination, efforts to build a full-bling harmony, to overcome ideologically false beliefs and spiritual divisions among nations, to respect the diversity of cultures, to enrich the cultures in the preservation of national peculiarities (Rtveladze, 2007). The reasons for raising the role of culture among other methods in the foreign policy of the state are their effectiveness in the process of coordinating international relations that have been proven by history.

\section{Literature review}

If we talk about Kazakhstan-British relations, then in 1991, few in the UK knew about the existence of the sovereign state of Kazakhstan (Svanberg, 1999). But a month after our country gained independence and the establishment of diplomatic relations, the British began to receive the first ideas about the steppe country (Paksoy, 1994). Diplomatic relations between our countries were established exactly one month after our country gained independence. Now the two states have reached a high level of strategic partnership (Tishkov, 1996). For example, the first visit of the First President of Kazakhstan to Great Britain took place in the same year. A few years later, members of the British royal family and other dignitaries began visiting Kazakhstan. Now Kazakhstan and the United Kingdom are connected by hundreds of joint projects, billions of investments and, of course, by people - Kazakhstan students studying in the UK, diplomats and their families, hundreds of Britons working in Kazakhstan. The president's visit to London gave a powerful impetus to the development of Kazakh-British relations (Richmond, 2000).As a result of the visit, dozens of documents were signed, as well as a number of agreements, including the provision of mutual legal assistance in the field of public service and the creation of the Astana International Financial Center. And if you show the chronology of the beginning of diplomatic relations between the two countries, then from October 1992 the British Embassy in the Republic of Kazakhstan has been operating. Since February 1996, the Embassy of the Republic of Kazakhstan in the UK has been operating. Since February 2017, E. Idrisov has been the Ambassador of the Republic of Kazakhstan to the United Kingdom. Since January 2018, M. Gifford was the British Ambassador to the Republic of Kazakhstan (Human, 2002). If we talk about cultural and humanitarian cooperation, then since 2001 Kazakhstan-British Technical University (KBTU) has been operating in Almaty, partners of which are leading universities in the UK. The program of preparation for university education, as well as the project to create an engineering school is implemented at Nazarbayev University with the support of University College London. Today, about 300 students are enrolled in the Bolashak program in the UK. In September 2019, as part of the implementation of the "Ruhani jangyry" program, the Public Fund of the National Translation Bureau, together with the Cambridge University Press, with the support of the Embassy of the Republic of Kazakhstan in the United Kingdom, published collections of articles of Kazakh poetry and prose. Translation of collections of Kazakh 
literature was carried out with the participation of experienced British experts in the field of literary translation. It is well known that the British Council is an international organization for cultural relations and educational opportunities in the UK. And in Kazakhstan, over the years of independence, the Council regularly and successfully holds many educational and cultural events. In order to implement the agreements in the field of education and science reached during the official visit of the First President of the Republic of Kazakhstan N. Nazarbayev to the United Kingdom of Great Britain and Northern Ireland in November 2000, Kazakhstan-British Technical University JSC was established (Decree No. 1027 of August 32001 in accordance with the Memorandum of Understanding between the Ministry of Education and Science of the Republic of Kazakhstan and the British Council). From the Kazakh side, the founder was the Government of the Republic of Kazakhstan represented by the Ministry of Education and Science, from the British side, the British Embassy in Kazakhstan and the British Council became partners of KBTU.

Today, our sovereign country has gained a worthy reputation and worthy experience of inter-religious measures and cultural harmony. Kazakhstan has signed cultural cooperation agreements with many countries near and far abroad and international organizations. (Karymsakova, 2007) Our country conducts the course in accordance with international obligations - this is education, science, theater, cinema, sports, art and literature, which are directly organized between institutions of a culture of peace. And at the same time, implements international projects in the fields. In Kazakhstan, there is a tradition of holding events such as "Year of Abay" and similar "Days", which are based on spiritual and intellectual events to enhance cultural exchange. Obviously, this will undoubtedly contribute to promoting national interests, popularizing the countries cultural and artistic achievements in the world for create a favorable image of the country based on the principles of openness and harmony. Today, cultural and humanitarian cooperation with other countries is developing dynamically. There are several activities in this area: to strengthen cultural and humanitarian ties with Kazakhstan and neighboring countries, Kazakhstan, Russia, Russia in Kazakhstan, Kazakhstan in Germany, Germany in Kazakhstan, Kazakhstan in China, China in Kazakhstan, etc. Many projects have been developed to strengthen cultural and humanitarian cooperation. Measures taken within the framework of this project contribute to the intensification of Kazakhstan's relations with far-abroad countries. For example, in Germany in 1998 the Days of Culture and Arts of the Republic of Kazakhstan were successfully held. The Kazakh diaspora, also living in Germany, also participated in the event. 2009-2010 Significant documents were signed within the framework of the Year of Kazakhstan in Germany and Germany in Kazakhstan. There are many issues in the cultural and humanitarian sphere: the opening of the Kazakhstan-German University in Almaty, joint declarations on partnership for the future, declarations on innovation and investment partnership, etc. A number of Kazakhstan and German higher education institutions, such as the University of Weisenstefan and Agrarian Universities in Almaty and Nur-Sultan, have partnership relations. For the purpose of reforming higher education institutions in Kazakhstan, German and German higher education institutions are working together within the European Union's TEMPUS / TACIS project.

\section{Material and methods}

As mentioned above, since the establishment in 1992 of diplomatic relations between Kazakhstan and Britain, and already at the existing Embassies of both countries, each other, in areas such as political relations between Kazakhstan and the UK, a constructive dialogue has been established, facilitated by the regular exchange of visits at all levels. Since the establishment of diplomatic relations, nine visits of the President of Kazakhstan to the UK have taken place (in 1991, 1992, 1994, 1997, 2000, 2006, 2012, 2013 and 2015), positive dynamics of trade and economic cooperation was noted, in 2019, in conjunction with the investment forum, the 3rd meeting of the Kazakhstan-British Business Council was held, during which the «Samruk-Kazyna» Foundation signed an Agreement on the basic conditions for the creation of a New Technology Fund with the «Da Vinci Capital» Fund and the Agreement on co-investing in renewable energy projects with «EDP Renovaveis» (Official website of the Ministry of Foreign Affairs of the Republic of Kazakhstan, 2020).In addition, on October 24, 2019, the 6th meeting of the Kazakhstan-British Intergovernmental Commission on Trade, Economic, Scientific, Technical and Cultural Cooperation (IPC), which 
was held in London under the co-chairmanship of the Deputy Minister of Foreign Affairs of the Republic of Kazakhstan R. Vasilenko and British Minister of State for Trade Policy C. Burns. And in order to implement the agreements in the field of education and science reached during the official visit of the First President of the Republic of Kazakhstan N. Nazarbayev to the United Kingdom of Great Britain and Northern Ireland in November 2000, the Kazakh-British Technical University of the AO was established (Decree No. 1027 dated August 3, 2001 in accordance with the Memorandum of Understanding between the Ministry of Education and Science of the Republic of Kazakhstan and the British Council). From the Kazakh side, the founder was the Government of the Republic of Kazakhstan represented by the Ministry of Education and Science, from the British side, the British Embassy in Kazakhstan and the British Council became partners of KBTU. Since 2003, the sole shareholder of KBTU JSC has been NC KazMunayGas JSC (Decree of the Government of the Republic of Kazakhstan No. 987 dated September 26, 2003). In 2003, with the aim of professional retraining and advanced training of personnel, the educational center of the Institute of Engineering and Information Technologies KBTU LLP was established. Since 2005, the KBTU and London School of Economics and Political Science double-degree educational programs have been in operation. In 2010 - 2011 100\% blocks of shares of JSC Institute of Fuel, Catalysis and Electrochemistry named after D.V. Sokolsky “, founded in 1969, and JSC" Institute of Chemical Sciences. A.B. Bekturova", formed in 1945. In 2018, a stake in Kazakhstan-British Technical University JSC as part of the implementation of the Privatization Program, approved by Decree of the Government of the Republic of Kazakhstan No. 1141 dated 12/30/2015, was purchased by the Public Fund "Education Fund of Nazarbayev".

\section{Scientific methodology}

At the same time, the fruitful cooperation between Kazakhstan and Russia in the field of science, education, and culture is based on the "Friendship and Cooperation Agreement". This which guarantees the survival and development of national identity in our countries, realization of their spiritual and religious needs, education in national languages, development of free and equal rights. Cooperation
Agreement "is based on bilateral documents. In 1998, Kazakhstan's cultural days and anniversary celebrations were held. Cultural events dedicated to the 180th anniversary of Kurmangazy Sagyrbaevich were held in Turkmenistan, the Republic of Turkey, the Kyrgyz Republic, as well as Moscow, Astrakhan, Russia (Landau, 2001). The fact that 4,000 Kazakh students are currently studying in the UK and that Kazakh students are issued more visas than from Australia or Brazil attests to the value of education in the UK. The United Kingdom is the most popular destination for graduate students at the Bolashak program, and the British government has also funded Chevening scholarships for more than 200 Kazakhstani graduate students, after which many return home to leadership positions."This is a way to build strong ties between the UK and Kazakhstan in the future," Gifford said. "We also have many institutional ties. The London School of Economics and the University of London collaborate with the Kazakh-British Technical University; The University of Cambridge collaborates with Nazarbayev Intellectual Schools, while Coventry University, Loughborough University and many others also work here. I was very impressed with the willingness of British institutions to look at Kazakhstan to establish partnerships." "We are increasingly participating in cultural cooperation through the British Council," he added. "Cambridge University Press is working with the National Translation Bureau of Kazakhstan to prepare an English-language anthology of Kazakh literature, which will be an important cultural milestone. The British Council also helps Kazakhstan develop its own creative industries, because in the UK, the creative economy is a very important part of our national economy. We have been hosting the Creative Central Asia forum in the region for several years. Last year, creative economics leaders from Central Asia and the United Kingdom gathered in Nur Sultan to discuss ideas and ways to develop creative industries on a more solid basis " (Weintal, 2002) The ambassador, who has become recognizable from his video blogs on Facebook (British Embassy Kazakhstan) and Twitter (@MikeGiffordFCO), also hopes to continue studying Kazakh and Russian languages and travel more around Kazakhstan. All this confirms the friendly moods and relations both on the part of states and their representatives. Which, of course, shows the development of bilateral relations in the future. 


\section{Conclusions}

The jubilee, dedicated to the 185th anniversary of the great Kazakh composer Kurmangazy Sagyrbayuly in Astrakhan region, organized in Kazakhstan in Russia in 2004, Russia's Year of Kazakhstan in 2004. And the 90th anniversary of Shaken Aimanov, the founder of Kazakh cinema in Omsk Days of cinema, among the most important events are the Kazakh culture in the new stage of the Big State Academic Theater of Russia ships' concert, etc. a clear example of cultural events. D i p 1 o matic relations between Kazakhstan and India were established in February 1992. In October 1992, the First Deputy Foreign Minister of India Rubi Bhatia arrived in Kazakhstan for an official visit. After the official visit of the First Deputy Foreign Minister of India, bilateral relations between Kazakhstan and India have intensified. In particular, the article is devoted to the cultural partnership of Kazakhstan with many foreign countries. In January 1994 the literary evening of Kazakh poet Amanzhol Shamkenov was held in Delhi. From November 29 to December 5, 1994 the delegation of Indian writers and poets from Almaty, famous writer Ananta Murti, visited Almaty. According to the Cultural Partnership Statement, in 1997, protocols on cultural exchanges and interdepartmental plans were signed. 62 tourist organizations and firms in Kazakhstan have established partnerships with their colleagues in India. There are sporting links between individual federations and clubs. In accordance with the agreements between hockey, volleyball, judo, archery and football federation on grass, in the conditions of India and Kazakhstan the athletes held joint trainings and meetings of the above-mentioned sports. An important event in strengthening cultural cooperation was the celebration of the 150th anniversary of Abai in India and the 125th anniversary of Mahatma Gandhi in Kazakhstan, Abai's poems were translated into Hindi, etc. A delegation from India arrived in Kazakhstan to celebrate the anniversary of Abay. The Indian Training Center was opened at the Eurasian National University in March 2000 (Richmond, 2000). And in the A. Kasteev Museum in Almaty, Indian Independence Day is constantly celebrated and scientific reports, as well as songs and dances performed by talented youth, are heard. For example, in 2019 there was an exhibition of works by artists such as Roerich. Of course, such cultural and humanitarian cooperation will also be useful in the trade, economic and political dialogue between the two countries. The foreign policy of any state is based on its cultural, ideological and national interests reflected in international politics. It is important to consider that great states are fighting for their own interests. That is why culture has a significant impact on the country's international relations. Extensive historical and textual studies, as well as comprehensive studies of the ancient manuscripts of Abay Kunanbaev, Turagul Abaevich, Muresseyt Bukeev and Akhat Shakarimuly, were carried out by the Ministry of Culture of the Republic of Kazakhstan as part of the cultural project "National Cultural Heritage". Different types of cfragic, heraldic and epigraphic materials have been collected in world libraries, their translation, research and translation of texts written in these products, their scientific paintings, as well as writing of sketches, texts of drawings and photographs have been completed. The collections of these collections were systematized, and most useful chronology and timing were determined. The texts from the epigraphic data are translated from Arabic, Persian, Tibetan, Manjur and Old Turkic languages. As a result of the competent and balanced policy of our state, we can see that our country is strengthening trade, economic, cultural and humanitarian ties with the countries of the world. Kazakhstan's relations with world countries are developing not only in economic and political spheres, but also in the cultural sphere. The multivector policy of the country intends to cooperate in all spheres with all countries of the world, aspiring to friendly cooperation. Culture and politics are closely interconnected, so they cannot be separated from one another. The foreign policy of any state is based on its cultural, ideological and national interests reflected in international politics. We should remember that great states are fighting for their own interests. That is why culture has a significant impact on the country's international relations. And the reflection of cultural relations in the media has its own characteristics and role in the harmonization of interstate relations. 


\section{References}

Alaolmolki, Nozar. Life after the Soviet Union: the new independent republics of Transcaucasia and Central Asia. Albany, NY: State University of New York Press, 2001.

Akiner, Shirin. The formation of the Kazakh identity: from the tribe to the national state. London: Human Rights Watch. "Kazakhstan”. Human Rights Watch World Report 2002.

Royal Institute of International Relations, Program for Russia and the CIS, 1995.

Карымсакова Р. Освещай, но не разжигай: Пособие для журналистов. - А., 2007.

Landau, Jacob M., and Barbara Kölner-Heinkel. Language policy in the former Soviet Muslim states: Azerbaijan, Uzbekistan, Kazakhstan, Kyrgyzstan, Turkmenistan and Tajikistan. Ann Arbor: University of Michigan Press, 2001.

Оразбекова 3.С, Жанабаев Е.Б. «СМИ и международные конфликты на евразийском пространстве». - Алматы: «Қазақ университеті», 2017.

Paksoy, HB, ed. Central Asian reader: rediscovering history. Armonk, New York and London: ME Sharp, 1994.

Постановление Правительства Республики Казахстан № 987 от 26 сентября 2003 г.

Ртвеладзе Э.В., СагдуллаевА.С. Современные мифы о далеком прошлом народов Центральной Азии. Ташкент: Чулпан, 2007.

Richmond, Simon.”Kazakhstan”. Central Asia, 2nd ed. Melbourne, Australia: Lonely Planet Publications, April 2000

Svanberg, Ingvar, ed. Modern Kazakhs: cultural and social prospects. New York: St. Martin's Press, 1999.

Тишков В. О толерантности // Этнополитический вестник, 1995. 5.

Тишков В. Миграции и новые диаспоры в постсоветских государствах. - М.,1996.

Weintal, Erica. State and environmental cooperation: linking domestic and international politics in Central Asia. Cambridge, Massachusetts: MIT Press, 2002.

\section{Электронные ресурсы}

Официальный сайт Министерства иностранных дел РК.: www.mfa.gov.kz

https://www.neweurasia.info

https://www.kazportal.kz/

$\mathrm{https}: / / 24 . \mathrm{kz} / \mathrm{ru} / \mathrm{tv}$

https://www.britishcouncil.kz/

\section{References}

Alaolmolki, Nozar. Life after the Soviet Union: the new independent republics of Transcaucasia and Central Asia. Albany, NY: State University of New York Press, 2001.

Akiner, Shirin. The formation of the Kazakh identity: from the tribe to the national state. London: Royal Institute of International Relations, Program for Russia and the CIS, 1995.

Human Rights Watch. "Kazakhstan”. Human Rights Watch World Report 2002.

Karymsakova R. Osveshchay, no ne razzhigay: Posobiye dlya zhurnalistov [Light but Don’t Kindle: A Handbook for Journalists]. A., 2007.

Landau, Jacob M., and Barbara Kölner-Heinkel. Language policy in the former Soviet Muslim states: Azerbaijan, Uzbekistan, Kazakhstan, Kyrgyzstan, Turkmenistan and Tajikistan. Ann Arbor: University of Michigan Press, 2001.

Orazbekova Z.C., Zhanabaev E.B., «SMI i mezhdunapodnyye konflikty na yevpaziyskom prpostranstve», «Kazak universitetí», [Media and international conflicts on the Eurasian space “,” Kazakh University”], Almaty, 2017.

Paksoy, HB, ed. Central Asian reader: rediscovering history. Armonk, New York and London: ME Sharp, 1994.

Postanovleniye Pravitel'stva Respubliki Kazakhstan [Decree of the Government of the Republic of Kazakhstan] № 987 dated September 26, 2003

Rtveladze E.V., Sagdullayev A.C. Sovremennyye mify o dalekom proshlom narodov Tsentral'noy Azii [Modern myths about the distant past of the peoples of Central Asia], Tashkent: Chulpan, 2007.

Richmond, Simon. "Kazakhstan”. Central Asia, 2nd ed. Melbourne, Australia: Lonely Planet Publications, April 2000

Svanberg, Ingvar, ed. Modern Kazakhs: cultural and social prospects. New York: St. Martin's Press, 1999.

Tishkov V. O tolepantnocti. Etnopoliticheckiy vectnik [About tolerance. Ethnic Political Newsletter], 1995,5.

Tishkov V. Migpatsii i novyye diacpopy v poctcovetckikh gocudapctvakh [Migrations and new diasporas in the post-Soviet states]. M.,1996.

Weintal, Erica. State and environmental cooperation: linking domestic and international politics in Central Asia. Cambridge, Massachusetts: MIT Press, 2002

Electronic resources:

Ofitsial'nyy sayt Ministerstva inostrannykh del RK.: [Official website of the Ministry of Foreign Affairs of the Republic of

Kazakhstan]www.mfa.gov.kz

https://www.neweurasia.info

https://www.kazportal.kz/

https://24.kz/ru/tv

https://www.britishcouncil.kz/ 